\title{
Organik olarak yetiştirilen palaz fındık çeşidinde ocaktaki gövde sayısına bağlı olarak verim ve meyve özelliklerindeki değişim
}

\author{
Kazım ÇALIŞKAN ${ }^{i}$ 1, Fikri BALTA ${ }^{i} 2$, Muharrem YILMAZ ${ }^{i D}$ 2, Orhan KARAKAYA ${ }^{\text {iD }}$ \\ ${ }^{1}$ Gıda Tarım ve Orman Bakanlığı, Çarşamba İlçe Tarım ve Orman Müdürlüğü, Çarşamba, Samsun \\ ${ }^{2}$ Ordu Üniversitesi, Ziraat Fakültesi, Bahçe Bitkileri Bölümü, Altınordu, Ordu \\ Alınış tarihi: 6 Aralık 2019, Kabul tarihi: 30 Aralık 2019 \\ Sorumlu yazar: Fikri Balta, e-posta: baltaf04@yahoo.com
}

\section{Öz}

$\mathrm{Bu}$ araştırma, Çarşamba ilçesi (Samsun) Çakmak Baraj havzasında organik tarıma geçiş sürecinde dördüncü yılını tamamlamış olan Palaz fındık çeşidiyle tesis edilmiş findık bahçelerinde 20152017 yılları arasında yürütülmüștür. Araştırmada 5, $6,7,8,10,12$ ve 14 gövdeli olarak terbiye edilmiș olan ocaklarda gövde sayısıyla bağlantılı olarak ocak verimi, gövde verimi ve bazı meyve özelliklerinin değişimleri incelenmiştir. Organik olarak yetiştirilen Palaz findık çeşidinde, ocakta bırakılan gövde sayısına bağlı olarak meyve ağırlı̆̆ 2.05-2.32 g, iç ağırlığı 1.12-1.29 g, iç oranı \%53.0-55.6, kabuk kalınlığı 1.08-1.20 mm, çotanaktaki meyve sayısı 2.35-2.65, ocak başına verim 1.223-7.290 kg, gövde verimi $244.6-595.4 \mathrm{~g}$ ve dekara verim $59.9-179.1 \mathrm{~kg}$ arasında hesap edilmiştir. Ocaktaki gövde sayısına bağlı olarak meyve ağırlığı, iç ağırlığı, kabuk kalınlığı ve iç oranı verileri arasında istatistiki önemli farklar bulunurken $(\mathrm{p}<0.05)$, ocak veriminin gövde sayısına bağlı olarak artış gösterdiği tespit edilmiştir. Üç yıllık ortalama değerlere göre, ocak başına en yüksek verim $7.290 \mathrm{~kg}$ ile bahçede $40.7 \mathrm{~m}^{2}$ lik bir yetişme alanı kaplayan 14 gövdeli ocaklardan, en yüksek gövde verimi 8 gövdeli ocaklardan elde edilmiştir. Bahçede $5,6,7,8,10,12$ ve 14 gövdeli olarak yetiştirilen ocakların geliştikleri taç iz düşüm (gelişme) alanları da sırasıyla $20.4 \mathrm{~m}^{2}, 22 \mathrm{~m}^{2}, 28.3$ $\mathrm{m}^{2}, 36.3 \mathrm{~m}^{2}, 37.4 \mathrm{~m}^{2}, 38.5 \mathrm{~m}^{2}$ ve $40.7 \mathrm{~m}^{2}$ olarak ölçülmüștür.

Anahtar kelimeler: Palaz, Organik, Verim, Gövde, Meyve
Changes in yield and nut traits depending on the stem number per ocak in grown organically in Palaz hazelnut cultivar

\section{Abstract}

This research was carried out in hazelnut orchards established with Palaz hazelnut cultivar which completed its fourth year in transition process to organic agriculture in Çakmak Dam Basin of Çarşamba district (Samsun Province). Changes in yields and nut traits of Palaz cultivar trained in 5, 6, $7,8,10,12$ and 14 stemmed shrubs in the orchards were studied for three years (2015-2017). Depending on the stem numbers of ocaks, Palaz cultivar had a range of 2.05-2.32 g for fruit weight, 1.12-1.29 g for kernel weight, 53.0-55.6 for kernel percentage, $1.08-1.20 \mathrm{~mm}$ for shell thickness and 2.35-2.65 for the number of nuts in cluster. According to the mean values of three years, the multi-stemmed ocaks yielded from $1.223 \mathrm{~g}$ to 7.290 $\mathrm{kg}$. The highest yield $(7.290 \mathrm{~kg})$ per ocak was obtained from 14 stemmed shrubs covering $40.7 \mathrm{~m}^{2}$ of growth area in the orchard. The yield amount per stem changed between $244.6 \mathrm{~g}$ and $595.4 \mathrm{~g}$. The highest yield per stem of ocaks was taken from 8 stemmed shrubs. Yield per da varied between 59.9 $\mathrm{kg}$ and $179.1 \mathrm{~kg}$. Depending on the number of stem on ocak, statistical differences were found for data of nut weight, kernel weight, shell thickness and kernel ratio. In the orchard $5,6,7,8,10,12$ and 14 stemmed ocaks developed in an area of $20.4 \mathrm{~m}^{2}, 22$ $\mathrm{m}^{2}, 28.3 \mathrm{~m}^{2}, 36.3 \mathrm{~m}^{2}, 37.4 \mathrm{~m}^{2}, 38.5 \mathrm{~m}^{2}$ ve $40.7 \mathrm{~m}^{2}$, respectively. The yield per ocak showed an increase in parallel with the stem number.

Key words: Palaz, Organic, Yield, Stem, Nut 


\section{Giriş}

Bilindiği gibi, organik tarım, kimyasal gübre ve pestisit gibi yapay girdiler kullanmadan, organik ve yeşil gübreleme, münavebe, toprağın muhafazası, bitkinin direncini arttırma ve biyolojik mücadeleden yararlanma yoluyla, çevre ve insan sağlığını tehdit etmeyen, toprak verimliliğini ve gida güvenliğini esas alan, sürdürülebilir verimliliğe dayalı, üretimden tüketime kadar tüm aşamaları kontrollü ve kayıt altında olan sertifikalı bir üretim biçimidir (Altındișli ve İlter, 2002). Dünya genelinde ve ülkemizce organik ürünlere olan taleple birlikte organik tarıma ayrılan üretim alanları da gittikçe artmaktadır.

Dünya fındık üretimi ve ihracatında lider ülke konumunda olan ve 675.000 ton kabuklu findik üretimi ile dünya üretiminin yaklaşık \% 67'sini karşılayan Türkiye (Anonim, 2019a), gerek konvansiyonel gerekse organik findık pazarında etkili olabilecek bir potansiyele sahiptir. Bu nedenle hem organik fındık üretimini hem de organik fındık mamüllerinde ürün çeşitliliğini artırmak durumundadır (Eryılmaz ve Kılıç, 2019).

Ülkemiz organik fındık üretimi 2017 yılı itibari ile toplam 15.096 tondur. Organik findık üretimi bakımından Samsun (4.443 ton) ili ilk sırada yer alırken, bu ilimizi Zonguldak (2.713 ton), Ordu (2.610 ton), Artvin (1.810 ton) ve Düzce (1.143 ton) illeri takip etmektedir (Anonim, 2019b). Diğer yandan, Türkiye'nin organik fındık ve fındık ürünleri ihracatı 2017 yllı itibariyle 31.941,92 dolara ulaşmış olup, tüm organik ürün ihracatının $\% 14,84$ 'ünü oluşturmuştur. Organik fındık ihracatımız başta Almanya olmak üzere daha çok Avrupa Birliği ülkelerine yapılmıştır (Anonim, 2019b).

Samsun'da organik fındık yetiştiriciliği 1994 yılında Terme ilçesi Çamlıca Köyünde yabancı bir firmanın organik findık talep etmesi ile başlamıştır (Aydoğan, 2012). İlde organik ürünler içerisinde üretim alanı bakımından ilk sırayı fındık almaktadır. İlde organik üretime geçiş birinci, ikinci, üçüncü ve organik ürün statüsünde 38.266 dekarlık alanda 5003 ton organik fındık üretilirken, Çarşamba ilçesinde bulunan Çakmak Barajı Havzası bu üretimde önemli bir payı teşkil etmektedir. Çarşamba ilçesinde organik tarım faaliyetleri Samsun'un içme suyunun sağlandı̆̆ Çakmak Barajının yapılmasından sonra 2004 yılında başlamıştır. İçme amaçlı kullanılan bu baraj suyunun kimyasal gübre ve ilaç kalıntılarıyla kirlenmesinin önüne geçmek ve insan sağlığını korumak amacıyla organik tarım projesi geliştirilerek, baraj havzasında baraja su taşıyan kanalların, çayların ve derelerin geçtiği 35 köyde uygulamaya geçilmiştir. Baraj havzasındaki köylerde mevcut yaklaşık 2500 çiftçinin 612'si organik tarıma geçmiştir. Çakmak Barajı Havzası'nda yer alan 35 köyde 15.964 da alanda 612 üretici ile organik fındık yetiştiriciliği yapılmaktadır (Anonim, 2017a).

Ülkemizde fındık yetiştiriciliği yaygın biçimde ocak sistemiyle yapılmakta olup (Beyhan, 2007; İslam, 2018), ocaktaki gövde sayısının 6 ile 12 arasında olması yetiştiricilikte kabul görmektedir (Bostan, 2005). Ülkemiz konvansiyonel fındık yetiştiriciliğinde dekara verim düşüklüğü sorunların başında gelmektedir. Yetiştiriciliğin geleneksel yöntemler ile yapılması, teknik ve kültürel uygulamalar konusundaki eksiklikler (Özkutlu ve ark. 2016; Külahçılar ve ark., 2018; Yaman, 2019) ile özellikle bazı yıllar ilkbaharda yaşanan olumsuz iklim şartları verim düşüklüğünün başlıca sebepleri arasındadır (Beyhan ve ark., 2007). Türkiye, $64.2 \mathrm{~kg}$ dekara findık verimi ile Amerika Birleşik Devletleri (269 kg), Fransa (221.3 kg), Çin (197.9 kg), Gürcistan (183 kg), Polonya (137.5 kg), Azerbaycan (118.2 kg), İtalya (104.6 kg), İspanya (99.6 kg) ve İran'dan $(91.5$ $\mathrm{kg}$ ) sonra onuncu sirada gelmektedir (Anonim, 2017b).

Benzer şekilde, findıkta verim düşüklüğü ve sebepleri, ülkemiz organik findık yetiştiriciliği için de geçerlidir. Bu nedenle, hem konvansiyonel (Bostan, 1997; İslam ve Özgüven, 1997; Karadeniz ve ark., 2009; Güler, 2017), hem organik fındık üretiminde verim ve kaliteyi artırmaya yönelik araştırmalar yürütülmesi önem arz etmektedir. Kisıtlı girdilerle üretim yapılma zorunluluğundan dolayı, organik findık üretiminden elde edilen verim konvansiyonel üretimden elde edilene nazaran daha düşüktür. Fakat, organik fındık konvansiyonel fındığa göre piyasada daha fazla değer bulmaktadır. Ayrıca, Tarım ve Ormancilık Bakanlığı tarafından verilen desteklerle organik findık tarımı teşvik edilmektedir.

$\mathrm{Bu}$ araştırma, Samsun İli Çarşamba İlçesi Çakmak Barajı Havzasında Organik olarak yetiştirilen Palaz fındık çeşidinde ocakta bırakılan gövde sayının verim ve meyve kalite özellikleri üzerine etkilerini belirlemek amacıyla 2015-2017 yılları arasında yürütülmüştür. 


\section{Materyal ve Yöntem}

\section{Materyal}

Çalışma 2015-2017 yılları arasında Samsun İli Çarşamba ilçesi Çakmak Barajı Havzası'nda bulunan Şeyhgüven Mahallesinde üç yıl süreyle yürütülmüştür. Çalışmanın materyalini, bölgede sertifikalı organik fındık yetiştiriciliği yapılan, organik üretime geçiște dördüncü yılını tamamlamıș, konumları birbirine yakın bahçelerde, Palaz çeșidine ait, yaşları 20 civarında, ocaklar arası dikim mesafeleri 5.0-6.5 m x 3.0-5.5 m arasında değișen ve gövde sayıları birbirinden farklı findık ocakları oluşturmuştur.

\section{Yöntem}

Araştırmada, Palaz çeşidiyle tesis edilmiş bahçelerde ocak başına gövde sayısı 5, 6, 7, 8, 10, 12 ve 14 olarak terbiye edilmiş yedi uygulama grubu belirlenmiştir. Belirlenen ocaklarda üç yıl süreyle hasattan önce çotanak sayımı yapılmıştır. İşaretlenen tüm ocaklardaki meyveler ayrı ayrı hasat edilmiş, zuruflarından ayrılıp doğal yolla kurumaya bırakılmış, ardından tartım yapılarak ocak başına verimler (g) kaydedilmiştir. Gövde verimi, ocak başına elde edilen verimin ocaktaki gövde sayısına bölünmesi ile hesap edilmiștir. Ocaklarda gövde çevreleri yerden $30 \mathrm{~cm}$ yükseklikten ölçülerek, gövde verim etkinliği hesaplanmıştır. Çalışmada ocakların bahçe içerisinde kapladıkları alanın belirlenmesi amacı ile taç iz düşüm alanı ( $\mathrm{m}^{2} /$ ocak) hesaplanmıştır. Buna göre, taç iz düşüm (gelişme) alanı $5,6,7,8,10,12$ ve 14 gövdeli ocaklarda sırası ile $20.4 \mathrm{~m}^{2}, 22 \mathrm{~m}^{2}, 28.3 \mathrm{~m}^{2}, 36.3 \mathrm{~m}^{2}, 37.4 \mathrm{~m}^{2}, 38.5 \mathrm{~m}^{2}$ ve $40.7 \mathrm{~m}^{2}$ olarak kaydedilmiștir. Ayrıca 5, 6, 7, 8, 10, 12 ve 14 gövdeli ocaklar için gövde kesit alanına ve dekara verimler (kg) hesap edilmiştir. Tesadüf Parselleri Deneme Desenine göre üç tekerrürlü olarak tertip edilen araştırmada, her tekerrüre bir ocak düşecek şekilde toplam yirmi bir ocak üzerinde araştırma yürütülmüştür. Araştırma yapılan fındık bahçelerinde bitkilerin beslenmesi amacıyla ocak başına 3-4 kg yanmış çiftlik gübresi uygulaması (Ocak ve Şubat aylarında) ile bir defa sıvı yaprak gübresi uygulaması (Mayıs sonu-Haziran ortası) yapılırken, hastalık ve zararlılar için herhangi bir ilaçlama yapılmamıştır. Bahçelerde uygun aletlerle yabancı ot temizliği titizlikle yürütülmüștür. Bunun yanında, hasat edilen meyve örneklerinde çok detaylı pestisit analizleri yapılmıștır.

Çalışmada meyve özellikleri olarak meyve ve iç ağırlığı, kabuk kalınlığı, iç oranı, kabuklu ve iç meyve boyutları, kusurlu iç oranı, buruşuk iç oranı, sağlam iç oranı, çift iç oranı, boş meyve oranı, çotanaktaki meyve sayısı ve dağılımı, protein, yağ ve kül oranları belirlenmiştir. Kabuklu ve iç meyve boyutları ölçülürken, meyve tablası ile uç kısım arası meyve boyu, iki kotiledon çizgisi (sutur) arası meyve genişliği, iki yanak arası meyve kalınlığı olarak kaydedilmiştir. Meyve özelliklerinin belirlenmesi için her tekerrürden alınan 30 adet meyve örneği kullanılmıştır. Çalışmada meyve ağırlığı ve iç ağırlığı $0.01 \mathrm{~g}$ hassasiyetindeki dijital terazi (Radwag, AS 220/C/2, Polonya) kullanılarak belirlenmiştir. Kabuk kalınlığı, kabuklu ve iç meyve boyutları ise $0.01 \mathrm{~mm}$ hassasiyetindeki dijital kumpasla (Mitutuyo, CD15CP, Japonya) ölçülmüştür (İslam, 2003; Bostan ve Karadeniz, 2004; Balta ve ark., 2018a,b). Çalışmada yağ oranı soxhalet ekstraksiyon cihazı kullanılarak, protein oranı ise kjeldahl yöntemine göre belirlenmiştir (Venktachalam ve ark., 2006). Kül oranı ise hazırlanan örneklerin $550{ }^{\circ} \mathrm{C}$ 'de kül fırınında yakılması ile tespit edilmiştir (AOAC, 1990). Elde edilen veriler SPSS 22.0 istatistik paket programı ile analiz edilmiştir. Ortalama değerler arasındaki farklılık ise Tukey çoklu karşılaştırma yöntemine göre \%5 önem seviyesinde belirlenmiştir.

\section{Bulgular ve Tartışma}

Organik olarak yetiştirilen Palaz fındık çeşidinde ocaktaki gövde sayısına bağlı olarak tespit edilen meyve ve verim özelliklerine ait bulgular Çizelge 1, 2, $3,4,5,6$ ve 7 'de sunulmuştur.

Çizelge 1. Organik olarak yetiştirilen Palaz çeşidinde meyve ve iç ağırlığı, kabuk kalınlığı ve iç oranı değerleri

\begin{tabular}{|c|c|c|c|c|}
\hline $\begin{array}{c}\text { Gövde } \\
\text { Sayısı/ } \\
\text { Ocak }\end{array}$ & $\begin{array}{l}\text { Meyve Ağırlığı } \\
\text { (g) }\end{array}$ & $\begin{array}{l}\text { İç Ağırlığı } \\
\text { (g) }\end{array}$ & $\begin{array}{l}\text { Kabuk Kalınlığı } \\
\qquad(\mathrm{mm})\end{array}$ & $\begin{array}{c}\text { İç Oranı } \\
(\%)\end{array}$ \\
\hline 5 & $2.15 \mathrm{bc}$ & $1.17 \mathrm{bc}$ & $1.14 \mathrm{bc}$ & $54.57 \mathrm{ab}$ \\
\hline 6 & $2.05 \mathrm{c}$ & $1.12 \mathrm{c}$ & $1.09 \mathrm{~cd}$ & $54.54 \mathrm{ab}$ \\
\hline 7 & $2.20 \mathrm{ab}$ & $1.22 \mathrm{ab}$ & $1.20 \mathrm{a}$ & 55.30 a \\
\hline 8 & $2.27 \mathrm{ab}$ & $1.26 \mathrm{a}$ & $1.09 \mathrm{~cd}$ & 55.58 a \\
\hline 10 & $2.32 \mathrm{a}$ & $1.23 \mathrm{ab}$ & $1.15 \mathrm{~b}$ & $53.01 \mathrm{c}$ \\
\hline 12 & $2.28 \mathrm{a}$ & $1.24 \mathrm{ab}$ & $1.19 \mathrm{ab}$ & $54.46 \mathrm{ab}$ \\
\hline 14 & $2.22 \mathrm{ab}$ & $1.19 \mathrm{ab}$ & $1.08 \mathrm{~d}$ & $53.83 \mathrm{bc}$ \\
\hline
\end{tabular}

$(\mathrm{p}<0.05)$

Meyve ağırlığı, iç ağırlığı, kabuk kalınlığı ve iç oranı değerleri arasında istatistiki farklar ocakta bırakılan gövde sayısına bağlı olarak önemli $\quad(\mathrm{p}<0.05)$ bulunmuştur. Gövde gruplarına bağlı olarak meyve ağırlığı 2.05-2.32 g, iç ağırlığı 1.12-1.26 g, kabuk kalınlığı 1.08-1.20 mm ve iç oranı \%53.01-55.58 
arasında değişmiştir. Meyve ağırlığı ve iç ağırlığı bakımından 7, 8, 10, 12 ve 14 gövdeli ocaklar istatistiksel olarak aynı grupta yer almışlardır. 6, 8 ve 14 gövdeli ocaklar en düşük kabuk kalınlığı değerine sahip olarak belirlenmiştir. İç oranı bakımından 5, 6, 7, 8 ve 12 gövdeli ocaklar arasındaki fark istatistiksel olarak benzer bulunmuştur (Çizelge 1). Karaosmanoğlu (2018) dışında, Palaz findık çeşidine ait organik yetiştiricilikle ilgili araştırmalara literatürde rastlanmamıștır. Karaosmanoğlu (2018), Ordu ve Samsun illerinde organik olarak yetiștirilen Palaz fındık çeşidinde, sırasıyla meyve ağırlığını $2.01 \mathrm{~g}$ ve $1.81 \mathrm{~g}$, iç ağırlığını $1.11 \mathrm{~g}$ ve $0.97 \mathrm{~g}$, kabuk kalınlığını $0.95 \mathrm{~mm}$ ve $0.92 \mathrm{~mm}$ ve iç oranını \%54.28 ve \%53.46 olarak belirlemiştir. Karaosmanoğlu (2018)'un belirlediği değerlere nazaran; bu araştırmadan elde edilen meyve ağırlığı, iç ağırlığı ve kabuk kalınlığı değerleri ile 7-8 gövdeli ocakların iç oranı değerleri daha yüksek, 5-6-10-12-14 gövdeli ocakların iç oranı değerleriyle benzer bulunmuştur. Turan ve ark. (2007), çeşitli organik gübrelerin findıkta verim, meyve ağırlığı, iç ağırlığı, iç oranı, kabuk kalınlığı ve sağlam iç oranı üzerine etkisinin çoğunlukla istatistiki olarak önemsiz çıktığını bildirmiştir.
Diğer yandan, Palaz çeşidi üzerine yapılan konvansiyonel yetiştiricilikle ilgili çalışmalarda; Balta ve ark., (1997) Çarşamba ve Terme ilçelerinde meyve ağırlığını 2.05-2.32 g, iç ağırlığını 1.17-1.28 g, iç oranını \%53.8-57.5 ve kabuk kalınlığını 0.82-0.94 mm; Bostan ve İslam (1999), Ordu ilinde meyve ağırlığını 1.91-2.72 g, iç ağırlığını 0.98-1.43 g, iç oranını \%41.9-60.5 ve kabuk kalınlığını 0.61-0.97 $\mathrm{mm}$; Beyhan (2007), Terme ilçesinde meyve ağırlığını 1.43-1.49 g, iç ağırlığını 0.85-1.20 g ve iç oranını \%43.6-48.8; Bak (2010), Ordu yöresinde 4, 5, $6,7,8,9$ ve 10 gövdeli ocaklarda meyve ağırlı̆̆ını 1.54-1.91, iç ağırlığını 0.77-1.02 g, iç oranını \%50.554.2 ve kabuk kalınlığını 1.08-1.28 mm; Balık ve Beyhan (2014), Ünye ilçesinde meyve ağırlığını 2.132.27 g, iç ağırlığını 1.14-1.21 g, iç oranını \%52.1-54.4 ve kabuk kalınlığını 0.98-1.18 mm arasında tespit etmişlerdir. Çalışmamızda belirlenen meyve ağırlı̆̆ı, iç ağırlığı, iç oranı ve kabuk kalınlığı değerleri araştırıcıların konvansiyonel yetiştiricilikle ilgili bulgularıyla genel olarak uyumlu iken, bazı araştırıcıların bulgularından farklı bulunmuştur. Konvansiyonel yetiştiricilikte görülen bu farklılıkların ekolojik koșullarından, yetiștirme modelleri, teknik ve kültürel uygulama farklılıkları ile beslenme şartları gibi nedenlerden kaynaklı olabileceği düşünülmektedir.

Çizelge 2. Organik olarak yetiştirilen Palaz fındık çeşidinde ocaktaki gövde sayısına bağlı olarak kabuklu ve iç meyve boyutları

\begin{tabular}{|c|c|c|c|c|c|c|}
\hline \multirow{2}{*}{$\begin{array}{c}\text { Gövde } \\
\text { Sayısı/Ocak }\end{array}$} & \multicolumn{3}{|c|}{ Kabuklu Meyve Boyutları } & \multicolumn{3}{|c|}{ İç Meyve Boyutları } \\
\hline & $\begin{array}{l}\text { Meyve Eni } \\
(\mathrm{mm})\end{array}$ & $\begin{array}{l}\text { Meyve Kalınlığ } \\
(\mathrm{mm})\end{array}$ & $\begin{array}{l}\text { Meyve Boyu } \\
(\mathrm{mm})\end{array}$ & $\begin{array}{c}\text { Meyve Eni } \\
(\mathrm{mm})\end{array}$ & $\begin{array}{l}\text { Meyve Kalınlığ } \\
(\mathrm{mm})\end{array}$ & $\begin{array}{c}\text { Meyve Boyu } \\
(\mathrm{mm})\end{array}$ \\
\hline 5 & 18.97 bc & $16.62 \mathrm{bc}$ & $17.31 \mathrm{~b}$ & $15.41 \mathrm{ab}$ & $13.66 \mathrm{a}$ & $13.43 \mathrm{~b}$ \\
\hline 6 & $18.89 \mathrm{c}$ & $16.44 \mathrm{c}$ & $17.15 \mathrm{~b}$ & $15.09 \mathrm{bc}$ & $13.26 \mathrm{bc}$ & $12.98 \mathrm{c}$ \\
\hline 7 & $19.26 \mathrm{abc}$ & $16.72 \mathrm{bc}$ & $17.80 \mathrm{a}$ & $15.55 \mathrm{a}$ & $13.54 \mathrm{ab}$ & $13.70 \mathrm{a}$ \\
\hline 8 & $19.42 \mathrm{a}$ & $17.14 \quad \mathrm{a}$ & $17.89 \mathrm{a}$ & $14.88 \mathrm{c}$ & $13.31 \mathrm{abc}$ & $13.72 \mathrm{a}$ \\
\hline 10 & $19.38 \mathrm{a}$ & $16.88 \mathrm{ab}$ & $18.11 \mathrm{a}$ & $14.96 \mathrm{c}$ & $13.61 \mathrm{ab}$ & $13.78 \mathrm{a}$ \\
\hline 12 & $19.35 \mathrm{ab}$ & $16.58 \mathrm{bc}$ & $17.41 \quad b$ & 15.21 abc & $13.61 \mathrm{ab}$ & $13.37 \mathrm{~b}$ \\
\hline 14 & 19.16 abc & $16.54 \mathrm{bc}$ & $17.42 \mathrm{~b}$ & $15.15 \mathrm{bc}$ & $13.00 \mathrm{c}$ & $13.34 \mathrm{~b}$ \\
\hline
\end{tabular}

$(\mathrm{p}<0.05)$

Kabuklu ve iç meyve boyutları arasında ocaktaki gövde sayısına bağlı olarak istatistiki önemli farklar $(\mathrm{p}<0.05)$ hesaplanmıştır. Gövde gruplarına göre kabuklu meyvede en, kalınlık ve boy değerleri sirasiyla 18.89 mm-19.42 mm, 16.44 mm-17.14 mm ve 17.15 mm-18.11 mm arasında ölçülmüştür. Gövde gruplarına göre iç meyvede meyve eni $14.88 \mathrm{~mm}$ $15.55 \mathrm{~mm}$, meyve kalınlığ $13.00 \mathrm{~mm}-13.66 \mathrm{~mm}$ ve meyve boyu $13.34 \mathrm{~mm}-13.78 \mathrm{~mm}$ arasinda belirlenmiştir (Çizelge 2). Karaosmanoğlu (2018),
Ordu ve Samsun illerinde organik olarak yetiștirilen Palaz findık çeşidinde, kabuklu meyvelerde sırasıyla meyve enlerini $18.94 \mathrm{~mm}$ ve $18.57 \mathrm{~mm}$, meyve kalınlıklarını $16.66 \mathrm{~mm}$ ve $16.33 \mathrm{~mm}$; meyve boylarını $16.44 \mathrm{~mm}$ ve $16.47 \mathrm{~mm}$, iç meyvelerde meyve enlerini $14.74 \mathrm{~mm}$ ve $13.36 \mathrm{~mm}$, meyve kalınlıklarını $13.54 \mathrm{~mm}$ ve $12.88 \mathrm{~mm}$, meyve boylarını $12.20 \mathrm{~mm}$ ve $12.10 \mathrm{~mm}$ olarak belirlemiștir. Karaosmanoğlu (2018)'un belirlediği değerlere göre; bu araştırmadan elde edilen kabuklu 
meyvelerde meyve eni ve kalınlığ değerleri benzer, meyve boyu değerleri daha yüksek; iç meyvelerde meyve eni ve boyu daha yüksek, meyve kalınlığı benzer bulunmuştur. Diğer yandan, Palaz çeşidi ile yapılan konvansiyonel yetiştiricilikle ilgili çalışmalarda; Bak (2010) ocaktaki gövde sayısına bağlı olarak kabuklu meyve boyunu 15.36 mm-16.43 mm, kabuklu meyve enini $17.00 \mathrm{~mm}-18.97 \mathrm{~mm}$, kabuklu meyve kalınlığını 14.49 mm-16.75 mm, iç meyve boyunu $11.37 \mathrm{~mm}-12.22 \mathrm{~mm}$, iç meyve enini 12.30 mm-13.55 mm ve iç meyve kalınlığını 10.70 mm-12.92 mm; Akçin (2010) Ordu yöresinde kabuklu meyve boyunu 16.80 mm, kabuklu meyve enini $19.60 \mathrm{~mm}$, kabuklu meyve kalınlığını 17.23 $\mathrm{mm}$, iç meyve boyunu $12.63 \mathrm{~mm}$, iç meyve enini 15.15 mm ve iç meyve kalınlığını $13.42 \mathrm{~mm}$; Balık ve Beyhan (2014) Ünye (Ordu) yöresinde kabuklu meyve boyunu 15.02-16.87 $\mathrm{mm}$, kabuklu meyve enini 17.27-19.94 mm, kabuklu meyve kalınlığını 15.03-17.57 mm, iç meyve boyunu $10.00 \mathrm{~mm}-12.70$ $\mathrm{mm}$, iç meyve enini 12.71-15.35 $\mathrm{mm}$ ve iç meyve kalınlığını 11.54-13.59 mm arasında belirlemişlerdir. Kabuklu ve iç meyve boyutları bakımından elde edilen bulgular araştırıcıların bulguları ile genel olarak benzerlik göstermektedir.

Çizelge 3. Organik olarak yetiştirilen Palaz fındık çeşidinde ocaktaki gövde sayısına bağlı olarak kusurlu, sağlam, buruşuk, boş ve çift iç oranları

\begin{tabular}{|c|c|c|c|c|c|}
\hline Gövde Sayısı/Ocak & Sağlam İç (\%) & Kusurlu İç (\%) & Buruşuk İç (\%) & Boş Meyve (\%) & Çift İç (\%) \\
\hline 5 & $91.6 \mathrm{~b}$ & $8.4 \mathrm{c}$ & 2.1 & 0.0 & 0 \\
\hline 6 & $95.8 \mathrm{a}$ & $4.2 \mathrm{~d}$ & 1.1 & 1.1 & 0 \\
\hline 7 & 95.8 a & $4.2 \mathrm{~d}$ & 2.1 & 0 & 1.1 \\
\hline 8 & $86.3 \mathrm{c}$ & $13.7 \mathrm{~b}$ & 0 & 4.2 & 2.1 \\
\hline 10 & $83.1 \mathrm{~d}$ & 16.9 a & 3.2 & 1.1 & 0 \\
\hline 12 & 95.8 a & $4.2 \mathrm{~d}$ & 1.1 & 0 & 1.1 \\
\hline 14 & $90.5 \mathrm{~b}$ & $9.5 \mathrm{c}$ & 1.1 & 0 & 0 \\
\hline
\end{tabular}

$(\mathrm{p}<0.05)$

Ocaktaki gövde sayısına bağlı olarak sağlam iç oranı $\% 83.1$ ile \%95.8, kusurlu iç oranı \%4.2 ile \%16.9, buruşuk iç oranı \%0 ile \%3.2, boş meyve oranı \%0 ile $\% 4.2$ ve çift iç oranı $\% 0$ ile $\% 2.1$ arasında tespit edilmiştir (Çizelge 3). Sağlam iç oranı bakımından 6, 7 ve 12 gövdeli ocaklar (\%95.8) istatistiksel olarak aynı grupta yer almıştır ( $\mathrm{p}<0.05) .10$ gövdeli $(\% 16.9)$ ve 8 gövdeli (\% 13.7) ocaklarda kusurlu iç oranları diğer gövde gruplarından yüksek bulunmuştur. Karaosmanoğlu (2018), Ordu ve Samsun illerinde organik olarak yetiştirilen Palaz fındık çeşidinde, sırasıyla sağlam iç oranını \%92.22 ve \%96.66, kusurlu iç oranını \%7.78 ve \%3.33 olarak bildirmiştir. $\mathrm{Bu}$ araştırmadan elde edilen sağlam iç oranı verileri, 8 ve 10 gövdeli ocakların verileri dışında, Karaosmanoğlu (2018)'nun verileriyle uyumlu, kusurlu iç oranı verileri ise araştırıcının verilerinden yüksek bulunmuştur. Bunun yanında, Beyhan (2007), Terme ilçesinde konvansiyonel olarak yetiştirilen Palaz çeşidinde sağlam iç oranını \%73.8-81.6, buruşuk iç oranını \%7.3-13.2 ve boş meyve oranını \%5.8-11.5 arasında bildirmiștir. Çalışmamızda sağlam iç oranı verileri Beyhan (2007)'nın değerlerinden yüksek, buna karşın boş meyve ve buruşuk iç oranları daha düșük bulunmuștur.

$\mathrm{Bu}$ araştırmada, meyve özellikleri açısından alınan sonuçlar, araştırmanın yürütüldüğü bahçelerde bakım şartlarının iyi olduğuna işaret etmektedir. Nitekim, konvansiyonel üretime göre organik findık üretiminde bir miktar ürün azalması olacağı için, yetiştiriciler bakım şartlarına daha çok özen göstermektedir.

Yedi farklı gövde grubuna göre yağ, protein ve kül oranları arasındaki fark istatistiksel olarak önemli $(\mathrm{p}<0.05)$ hesaplanmıştır. Ocaktaki gövde sayısına bağlı olarak yağ oranı \%63.9-68.0, protein oranı \%13.7-15.0 ve kül oranı \%2.03-2.23 arasında değişiklik göstermiştir (Çizelge 4). Yă̆ oranı bakımından 6, 7, 8, 10 ve 12 gövdeli ocaklar; protein oranı bakımından 8 gövdeli dişındaki tüm ocaklar; kül oranı bakımından ise 10 gövdeli dışındaki tüm ocaklar istatistiksel olarak aynı grupta yer almıştır. Karaosmanoğlu (2018), Ordu ilinde organik olarak yetiştirilen Palaz fındık çeşidinde yağ, protein ve kül oranlarını, sirasıyla \%53.36, \%15.93 ve \%2.53; Samsun ilinde organik olarak yetiștirilen Palaz findık çeşidinde ise sirasılyla $\% 54.55, \% 14.95$ ve $\% 2.53$ 
olarak belirlemiştir. Bu araştırmada belirlenen yağ içerikleri Karaosmanoğlu (2018)'un verilerine göre yüksek, buna karşın protein ve kül içerikleri bir miktar düşük bulunmuştur. Karaosmanoğlu (2018), organik tarım uygulamalarıyla fındık çeşitlerinde (Palaz dahil) besin kompozisyonlarında ve miktarlarında dikkate değer düşüşler kaydedilmediğini, hatta bazı besin içeriklerinde artışlar bile olduğunu belirleyerek, konvansiyonel üretimle aynı kalitede fındık üretilebileceğini bildirmiştir. Konvansiyonel araştırmalarda ise, Palaz fındık çeşidi için yağ içeriğini, Bostan ve ark. (2008) \%64-68, Baş ve ark. (1986) \%61.2-63.2 ve Bak (2010) \%60.8-66.5; protein içeriğini Baş ve ark. (1986) \%14-14.6 ve Bak (2010) \%10.6-15 arasında bildirmişlerdir. Çalışmamızda belirlenen yağ içeriği değerleri Bostan ve ark. (2008)'nın bulgularına benzer, Bak (2010)'ın değerleriyle kısmen benzer, Baș ve ark. (1986)'nın bulgularından yüksek bulunmuştur. Protein içeriği ise Baş ve ark. (1986)'nın verileriyle benzerlik göstermiştir. Konvansiyonel yetiştiricilikte görülen farklılıkların ekolojik koşullardan, teknik ve kültürel uygulama farklıllklarından, beslenme ve bakım şartlarından, ayrıca meyvelerin olgunluk durumlarından kaynaklı olabileceği düşünülmektedir.

Çizelge 4. Organik olarak yetiştirilen Palaz çeşidinde ocaktaki gövde sayısına bağlı olarak yağ, protein ve kül içerikleri (\%)

\begin{tabular}{cclll}
\hline $\begin{array}{c}\text { Gövde } \\
\text { Sayısı } \\
\text { /Ocak }\end{array}$ & Yağ (\%) & Protein (\%) & Kül (\%) \\
\hline 5 & 65.4 & bc & $14.6 \mathrm{a}$ & $2.03 \mathrm{ab}$ \\
6 & $66.3 \mathrm{abc}$ & $14.4 \mathrm{ab}$ & $2.21 \mathrm{ab}$ \\
7 & $67.8 \mathrm{ab}$ & $13.9 \mathrm{ab}$ & $2.13 \mathrm{ab}$ \\
8 & $68.0 \mathrm{a}$ & $13.1 \mathrm{~b}$ & $2.18 \mathrm{ab}$ \\
10 & $66.5 \mathrm{ab}$ & $15.0 \mathrm{a}$ & $2.20 \mathrm{~b}$ \\
12 & $65.7 \mathrm{abc}$ & $13.9 \mathrm{ab}$ & $2.12 \mathrm{ab}$ \\
14 & $63.9 \mathrm{c}$ & $13.7 \mathrm{ab}$ & $2.23 \mathrm{a}$ \\
\hline
\end{tabular}

$(p<0.05)$

Ocaktaki gövde sayısına bağlı olarak ocak başına çotanak sayısı ve çotanaktaki meyve sayısı arasındaki fark istatistiksel olarak önemli bulunurken $(\mathrm{p}<0.05)$, gövde başına çotanak sayısı arasındaki fark ise önemsiz bulunmuştur $(\mathrm{p}<0.05)$. Ocak başına ortalama çotanak sayısı 218.9 (5 gövdeli)-1323.4 (14 gövdeli); gövde başına ortalama çotanak sayısı 43.8 (5 gövdeli)-108.8 (8 gövdeli) ve çotanaktaki meyve sayısı 2.35 (6 gövdeli) ile 2.65 (5 gövdeli) arasında değişiklik göstermiştir. Gövde gruplarına göre çotanakların $\% 0-0.3^{\prime}$ ü $8^{\prime}$ li ve üzerinde, \%0-1.4'ü 7'li, \%1.2-2.1'i 6'll, \%2.3-5.7'si 5'li, \%6.8-14.2'si 4'lü, \%24.9-32.9'u 3'lü, \%31.638.6'sı 2'li ve \%14.4-24.7'si 1'li çotanaklar oluşturmuşlardır (Çizelge 5). Bak (2010), Ordu'da 4, 5, 6, 7, 8, 9 ve 10 gövdeli olarak yetiştirilen Palaz çeşidinde çotanaktaki meyve sayısını $2.76 \quad$ (4 gövdeli) ile 3.77 (10 gövdeli) arasında belirleyerek, çotanaktaki meyve sayısının yıllara göre dalgalanma gösterdiğini belirtmiştir. Konvansiyonel olarak yetiştirilen Palaz çeşidinde çotanaktaki meyve sayısını Ayfer ve ark., (1986) 3.2; Bostan, (1997) 2-3; İslam ve Özgüven (2001) 3.82 olarak bildirmiștir. Çotanaktaki meyve sayısı bakımından elde edilen bulgular araştırıcıların bulguları ile uyum içerisindedir. Bununla birlikte, Bak ve ark. (2014), ocak sistemiyle yetiştirilen Palaz çeşidinde çotanaktaki meyve sayısının yöneyden etkilendiğini belirlemişlerdir.

Ocaktaki gövde sayısına bağlı olarak 2015, 2016 ve 2017 yıllarında ocak verimi ve gövde verimi değerleri arasında istatistiksel olarak önemli $(p<0.05)$ bir farklılık belirlenmiştir. Ocak başına verim 2015 yılında $1.703-8.229 \mathrm{~kg}, 2016$ yılında 0.601-3.039 kg ve 2017 yllında $1.365-10.542 \mathrm{~kg}$ arasında değişmiştir. Üç yıl boyunca ocak verimi gövde sayısına paralel olarak artış göstermiştir. Üç ylllık ortalama değerlere göre en yüksek ocak verimi $7.290 \mathrm{~kg}$ ile 14 gövdeli ocaklarda belirlenirken, en düşük $1.223 \mathrm{~kg}$ ile 5 gövdeli ocaklarda tespit edilmiştir. Yıllara göre en yüksek ocak verimi 14 gövdeli ocaklarda, en düşük ise 5 gövdeli ocaklarda belirlenmiştir (Çizelge 6). Literatürde, Palaz çeşidinin organik üretimiyle ilgili dekara verim değerlerine rastlanmamıştır. Fakat, Tombul fındık çeşidiyle yapılan araştırmalarda; Özenç (2004) organik materyal uygulamalariyla $4.13-4.88 \mathrm{~kg}$, Özyazıcı ve ark. (2010) ise taze fındık zurufu ve organik ticari gübre uygulamalarıyla $5.5-6.0 \mathrm{~kg}$ arasında değişen ocak verimleri bildirmişlerdir.

Üç yıllık ortalama değerlere göre en yüksek gövde verimi $595.4 \mathrm{~g}$ ile 8 gövdeli ocaklarda bulunurken, en düşük 244.6 g ile 5 gövdeli ocaklarda belirlenmiştir. 2015 yllında en yüksek ocak verimi 14 (592.1 g) ve 8 (555.8 g), 2016 yllinda 8 (237.5 g) ve 10 (225 g), 2017 yllında 8 (992.8 g) ve 10 (870.8 g) gövdeli ocaklardan elde edilmiştir (Çizelge 7).

Bak (2010) Ordu'da konvansiyonel olarak 4, 5, 6, 7, 8, 9 ve 10 gövdeli yetiștirilen Palaz ocaklarında gövde başına verimi 1024.6-1460.1 g arasında belirlerken, ocaklarda bırakılabilecek gövde sayısının 8'i geçmemesi gerektiğini ifade etmiştir. 
Kırca (2010), Giresun ili Güce ilçesinde farklı yaşlara sahip bahçelerde konvansiyonel olarak yetiştirilen Tombul findık çeşidinde gövde verimini 307.84$665.73 \mathrm{~g}$ arasında tespit etmiştir. Çalışmamızda 3 yıllık ortalama değerlere göre en yüksek gövde verimi $595.4 \mathrm{~g}$ ile 8 gövdeli ocaklarda tespit edilmiştir. Gövde verim değerleri Bak (2010)'ın verilerine göre düşük, Kırca (2010)'nın verileriyle kısmen uyumlu bulunmuştur. Gövde verimi bakımından görülen farklılıkların ekolojik koşullardan, teknik ve kültürel uygulama farklılıklarından kaynaklı olabileceği düşünülmektedir.

Çizelge 5. Organik olarak yetiştirilen Palaz çeşidinde ocaktaki gövde sayısına bağlı olarak çotanak sayıları

\begin{tabular}{|c|c|c|c|c|c|c|c|c|c|c|c|c|}
\hline \multirow{3}{*}{ GS } & \multirow{3}{*}{ Yll } & \multirow{3}{*}{ OTÇS } & \multirow{3}{*}{ GBÇS } & \multirow{3}{*}{ ÇMS } & \multicolumn{8}{|c|}{ Çotanak sayısı/ocak ve \% dağılımı } \\
\hline & & & & & \multicolumn{2}{|l|}{1} & \multicolumn{2}{|c|}{2} & \multirow{2}{*}{$\frac{3}{4 \operatorname{det}}$} & \multicolumn{3}{|c|}{4} \\
\hline & & & & & Adet & $\%$ & Adet & $\%$ & & $\%$ & Adet & $\%$ \\
\hline \multirow[t]{4}{*}{5} & 2015 & 316 & 63.3 & 2.50 & 44 & 13.9 & 112 & 35.3 & 102 & 32.3 & 36 & 11.3 \\
\hline & 2016 & 100 & 20.0 & 2.79 & 12 & 11.8 & 32 & 31.5 & 31 & 31.4 & 17 & 17.4 \\
\hline & 2017 & 240 & 48.1 & 2.64 & 42 & 17.6 & 68 & 28.1 & 84 & 34.9 & 33 & 13.8 \\
\hline & Ort. & $218.9 \mathrm{~d}$ & 43.8 öd & $2.65 \mathrm{a}$ & 32.7 & 14.4 & 70.2 & 31.6 & 72.5 & 32.9 & 28.8 & 14.2 \\
\hline \multirow[t]{4}{*}{6} & 2015 & 421 & 70.2 & 2.23 & 117 & 27.7 & 152 & 36.2 & 116 & 27.5 & 18 & 4.3 \\
\hline & 2016 & 142 & 23.6 & 2.38 & 34 & 23.8 & 51 & 36.3 & 36 & 25.1 & 16 & 11.1 \\
\hline & 2017 & 392 & 65.3 & 2.43 & 85 & 21.6 & 170 & 43.4 & 87 & 22.1 & 20 & 5 \\
\hline & Ort. & $318.1 \mathrm{~cd}$ & 53.0 & $2.35 \mathrm{~b}$ & 78.3 & 24.4 & 124.6 & 38.6 & 79.3 & 24.9 & 17.8 & 6.8 \\
\hline \multirow[t]{4}{*}{7} & 2015 & 578 & 82.6 & 2.39 & 126 & 21.8 & 216 & 37.3 & 167 & 28.9 & 42 & 7.2 \\
\hline & 2016 & 249 & 35.6 & 2.69 & 45 & 18 & 81 & 32.4 & 66 & 26.3 & 36 & 14.6 \\
\hline & 2017 & 1070 & 152.9 & 2.48 & 285 & 26.6 & 324 & 30.3 & 255 & 23.8 & 123 & 11.5 \\
\hline & Ort. & $632.5 \mathrm{~b}-\mathrm{d}$ & 90.4 & $2.52 \mathrm{ab}$ & 151.9 & 22.1 & 206.9 & 33.3 & 162.5 & 26.3 & 67.0 & 11.1 \\
\hline \multirow[t]{4}{*}{8} & 2015 & 771 & 96.4 & 2.54 & 152 & 19.7 & 267 & 34.6 & 244 & 31.6 & 55 & 7.14 \\
\hline & 2016 & 313 & 39.1 & 2.67 & 61 & 19.5 & 91 & 29.1 & 82 & 26.3 & 58 & 18.5 \\
\hline & 2017 & 1526 & 190.8 & 2.29 & 420 & 27.5 & 539 & 35.3 & 398 & 26.1 & 93 & 6.1 \\
\hline & Ort. & $870.1 \mathrm{a}-\mathrm{d}$ & 108.8 & $2.50 \mathrm{ab}$ & 210.9 & 22.2 & 298.9 & 33.0 & 241.4 & 28.0 & 68.7 & 10.6 \\
\hline \multirow[t]{4}{*}{10} & 2015 & 852 & 85.2 & 2.46 & 178 & 20.9 & 294 & 34.5 & 273 & 32.1 & 59 & 6.9 \\
\hline & 2016 & 340 & 34.0 & 2.85 & 46 & 13.4 & 99 & 29.2 & 102 & 30 & 63 & 18.6 \\
\hline & 2017 & 1592 & 159.2 & 2.36 & 371 & 23.3 & 557 & 35 & 540 & 33.9 & 45 & 2.8 \\
\hline & Ort. & 927.9 a-c & 92.8 & $2.56 \mathrm{ab}$ & 198.2 & 19.2 & 316.8 & 32.9 & 305.0 & 32.0 & 55.5 & 9.4 \\
\hline \multirow[t]{4}{*}{12} & 2015 & 1066 & 88.9 & 2.42 & 232 & 21.8 & 370 & 34.7 & 325 & 30.5 & 78 & 7.3 \\
\hline & 2016 & 308 & 25.6 & 2.55 & 87 & 28.3 & 90 & 29.3 & 47 & 15.3 & 53 & 17.1 \\
\hline & 2017 & 1716 & 143.0 & 2.39 & 413 & 24.1 & 546 & 31.8 & 546 & 31.8 & 144 & 8.4 \\
\hline & Ort. & $1029.9 \mathrm{ab}$ & 85.8 & $2.45 \mathrm{ab}$ & 244.3 & 24.7 & 335.2 & 31.9 & 306.0 & 25.9 & 91.5 & 10.9 \\
\hline \multirow[t]{4}{*}{14} & 2015 & 1607 & 114.8 & 2.32 & 344 & 21.4 & 580 & 36.1 & 566 & 35.2 & 74 & 4.6 \\
\hline & 2016 & 484 & 34.6 & 2.83 & 58 & 12 & 154 & 31.8 & 143 & 29.6 & 90 & 18.5 \\
\hline & 2017 & 1879 & 134.2 & 2.53 & 365 & 19.4 & 630 & 33.5 & 616 & 32.8 & 171 & 9.1 \\
\hline & Ort. & $1323.4 \mathrm{a}$ & 94.5 & $2.56 \mathrm{ab}$ & 255.5 & 17.6 & 454.5 & 33.8 & 441.8 & 32.5 & 111.5 & 10.7 \\
\hline
\end{tabular}

( $\mathrm{p}<0.05)$; öd Önemli değil ( $\mathrm{p}<0.05)$. GS: Gövde sayısı/ocak, OTÇS: Ocağın toplam çotanak sayısı, GBÇS: Gövde başına düşen çotanak sayısı; ÇMS: Çotanak başına düşen meyve sayısı. 
Çizelge 5 (devamı).

\begin{tabular}{|c|c|c|c|c|c|c|c|c|c|}
\hline \multirow{3}{*}{$\begin{array}{c}\text { Gövde } \\
\text { sayısı/ } \\
\text { Ocak }\end{array}$} & \multirow{3}{*}{ Yll } & \multicolumn{8}{|c|}{ Çotanak sayısı/ocak ve \% dağılımı } \\
\hline & & \multicolumn{2}{|l|}{5} & \multicolumn{2}{|l|}{6} & \multicolumn{2}{|l|}{7} & \multicolumn{2}{|c|}{8 ve üzeri } \\
\hline & & Adet & $\%$ & Adet & $\%$ & Adet & $\%$ & Adet & $\%$ \\
\hline \multirow[t]{4}{*}{5} & 2015 & 21 & 6.5 & 3 & 0.8 & 0 & 0 & 0 & 0 \\
\hline & 2016 & 7 & 7.1 & 1 & 0.8 & 0 & 0 & 0 & 0 \\
\hline & 2017 & 9 & 3.6 & 5 & 2 & 0 & 0 & 0 & 0 \\
\hline & Ort. & 12.1 & 5.7 & 2.7 & 1.2 & 0.0 & 0.0 & 0.0 & 0.0 \\
\hline \multirow[t]{4}{*}{6} & 2015 & 12 & 2.9 & 6 & 1.4 & 0 & 0 & 0 & 0 \\
\hline & 2016 & 3 & 1.8 & 1 & 0.7 & 2 & 1.4 & 0 & 0 \\
\hline & 2017 & 8 & 2.1 & 11 & 2.9 & 11 & 2.9 & 0 & 0 \\
\hline & Ort. & 7.7 & 2.3 & 6.1 & 1.7 & 4.4 & 1.4 & 0.0 & 0.0 \\
\hline \multirow[t]{4}{*}{7} & 2015 & 14 & 2.4 & 14 & 2.4 & 0 & 0 & 0 & 0 \\
\hline & 2016 & 13 & 5.2 & 5 & 2 & 2 & 0.8 & 2 & 0.8 \\
\hline & 2017 & 54 & 5 & 20 & 1.9 & 10 & 0.9 & 0 & 0 \\
\hline & Ort. & 26.8 & 4.2 & 13.1 & 2.1 & 3.9 & 0.6 & 0.7 & 0.3 \\
\hline \multirow[t]{4}{*}{8} & 2015 & 23 & 3 & 15 & 2 & 15 & 2 & 0 & 0 \\
\hline & 2016 & 12 & 3.9 & 7 & 2.1 & 2 & 0.6 & 0 & 0 \\
\hline & 2017 & 46 & 3 & 23 & 1.5 & 8 & 0.5 & 0 & 0 \\
\hline & Ort. & 27.0 & 3.3 & 15.0 & 1.9 & 8.3 & 1.0 & 0.0 & 0.0 \\
\hline \multirow[t]{4}{*}{10} & 2015 & 29 & 3.4 & 9 & 1.1 & 9 & 1.1 & 0 & 0 \\
\hline & 2016 & 22 & 6.5 & 4 & 1.2 & 1 & 0.3 & 3 & 0.8 \\
\hline & 2017 & 45 & 2.8 & 25 & 1.6 & 10 & 0.6 & 0 & 0 \\
\hline & Ort. & 31.9 & 4.2 & 13.0 & 1.3 & 6.6 & 0.7 & 0.9 & 0.3 \\
\hline \multirow[t]{4}{*}{12} & 2015 & 33 & 3.1 & 22 & 2.1 & 0 & 0 & 5 & 0.5 \\
\hline & 2016 & 22 & 7.3 & 8 & 2.6 & 1 & 0.2 & 0 & 0 \\
\hline & 2017 & 33 & 1.9 & 22 & 1.3 & 12 & 0.7 & 0 & 0 \\
\hline & Ort. & 29.4 & 4.1 & 17.6 & 2.0 & 4.2 & 0.3 & 1.8 & 0.2 \\
\hline \multirow[t]{4}{*}{14} & 2015 & 29 & 1.8 & 14 & 0.9 & 0 & 0 & 0 & 0 \\
\hline & 2016 & 23 & 4.7 & 10 & 2 & 5 & 1 & 2 & 0.4 \\
\hline & 2017 & 41 & 2.2 & 28 & 1.5 & 28 & 1.5 & 0 & 0 \\
\hline & Ort. & 31.0 & 2.9 & 17.4 & 1.5 & 11.0 & 0.8 & 0.6 & 0.1 \\
\hline
\end{tabular}

Çizelge 6. Organik olarak yetiştirilen Palaz çeşidinde ocaktaki gövde sayısına bağlı olarak üç ylllık ocak verimi $(\mathrm{kg})$

\begin{tabular}{cccccccccccc}
\hline $\begin{array}{c}\text { Gövde } \\
\text { sayıs } \\
\text { /Ocak }\end{array}$ & \multicolumn{10}{c}{ Verim (kg/ocak) } \\
\cline { 2 - 10 } & 2015 & 2016 & 2017 & Toplam & & Ortalama \\
\hline 5 & 1.703 & $\mathrm{~g}$ & 0.601 & $\mathrm{~d}$ & 1.365 & $\mathrm{~g}$ & 3.668 & $\mathrm{~g}$ & & 1.223 & $\mathrm{~g}$ \\
6 & 1.926 & $\mathrm{f}$ & 0.691 & $\mathrm{e}$ & 1.953 & $\mathrm{f}$ & 4.570 & $\mathrm{f}$ & & 1.523 & $\mathrm{f}$ \\
7 & 3.034 & $\mathrm{e}$ & 1.475 & $\mathrm{c}$ & 5.837 & $\mathrm{e}$ & 10.346 & $\mathrm{e}$ & & 3.449 & $\mathrm{e}$ \\
8 & 4.446 & $\mathrm{~d}$ & 1.900 & $\mathrm{bc}$ & 7.943 & $\mathrm{~d}$ & 14.289 & $\mathrm{~d}$ & & 4.763 & $\mathrm{~d}$ \\
10 & 4.860 & $\mathrm{c}$ & 2.250 & $\mathrm{~b}$ & 8.708 & $\mathrm{c}$ & 15.818 & $\mathrm{c}$ & & 5.273 & $\mathrm{c}$ \\
12 & 5.872 & $\mathrm{~b}$ & 1.787 & $\mathrm{bc}$ & 9.348 & $\mathrm{~b}$ & 17.007 & $\mathrm{~b}$ & & 5.669 & $\mathrm{~b}$ \\
14 & 8.289 & $\mathrm{a}$ & 3.039 & $\mathrm{a}$ & 10.542 & $\mathrm{a}$ & 21.870 & $\mathrm{a}$ & & 7.290 & $\mathrm{a}$ \\
\hline
\end{tabular}

$(p<0.05)$ 
Çizelge 7. Organik olarak yetiştirilen Palaz çeşidinde ocaktaki gövde sayısına göre gövde verimi, gövde kesit alanı (GKA) ve gövde verim etkinliği (GVE).

\begin{tabular}{|c|c|c|c|c|c|c|c|c|c|c|c|c|}
\hline \multirow{3}{*}{$\begin{array}{c}\text { Gövde } \\
\text { Sayısı/ } \\
\text { Ocak } \\
5\end{array}$} & \multicolumn{8}{|c|}{ Gövde verimi (g) } & \multirow{2}{*}{\multicolumn{2}{|c|}{$\begin{array}{c}\text { GKA }^{1} \\
\left(\mathrm{~cm}^{2} / \text { gövde }\right)\end{array}$}} & \multirow{2}{*}{\multicolumn{2}{|c|}{$\begin{array}{c}\mathrm{GVE}^{1} \\
\left(\mathrm{~g} / \mathrm{cm}^{2}\right)\end{array}$}} \\
\hline & \multicolumn{2}{|c|}{2015} & \multicolumn{2}{|c|}{2016} & \multicolumn{2}{|c|}{2017} & \multicolumn{2}{|c|}{ Ortalama } & & & & \\
\hline & 340 & $\mathrm{e}$ & 120 & $\mathrm{~b}$ & 273 & $\mathrm{~g}$ & 245 & $\mathrm{e}$ & 9.8 & $\mathrm{~d}$ & 28 & $\mathrm{c}$ \\
\hline 6 & 321 & $\mathrm{f}$ & 115 & $\mathrm{~b}$ & 325 & $\mathrm{f}$ & 254 & $\mathrm{e}$ & 13.5 & $a-c$ & 24 & $\mathrm{c}$ \\
\hline 7 & 433 & $\mathrm{~d}$ & 210 & $\mathrm{a}$ & 834 & $\mathrm{c}$ & 493 & $\mathrm{c}$ & 11.2 & $\mathrm{~cd}$ & 74 & $\mathrm{a}$ \\
\hline 8 & 556 & $\mathrm{~b}$ & 237 & $\mathrm{a}$ & 993 & $\mathrm{a}$ & 595 & $\mathrm{a}$ & 15.7 & $\mathrm{ab}$ & 63 & $\mathrm{ab}$ \\
\hline 10 & 486 & $\mathrm{c}$ & 225 & $\mathrm{a}$ & 871 & $\mathrm{~b}$ & 527 & $\mathrm{~b}$ & 13.3 & $a-d$ & 66 & $\mathrm{a}$ \\
\hline 12 & 489 & $\mathrm{c}$ & 149 & $\mathrm{~b}$ & 779 & $\mathrm{~d}$ & 472 & $\mathrm{~d}$ & 16.1 & $\mathrm{a}$ & 49 & $\mathrm{~b}$ \\
\hline 14 & 592 & $\mathrm{a}$ & 217 & $\mathrm{a}$ & 753 & $\mathrm{e}$ & 521 & $\mathrm{~b}$ & 12.3 & b-d & 61 & $a b$ \\
\hline
\end{tabular}

(p<0.05) GKA: Gövde başına kesit alanı ( $\mathrm{cm}^{2} /$ gövde). GVE: Gövde başına verim etkinliği $\left(\mathrm{g} / \mathrm{cm}^{2}\right) . \mathrm{GVE}\left(\mathrm{kg} / \mathrm{cm}^{2}\right)=\mathrm{Gövde}(\mathrm{kg}) / \mathrm{GKA}\left(\mathrm{cm}^{2}\right)$

12017 yll verileri.

Yedi farklı gövde grubunda gövde verim etkinliği (DVE) ve gövde kesit alanı (GKA) değerleri arasındaki fark istatistiksel olarak önemli bulunmuştur $(\mathrm{p}<0.05)$. Ocaktaki gövde sayına bağlı olarak GKA değerleri $9.8 \mathrm{~cm}^{2}$ ile $16.1 \mathrm{~cm}^{2}$, GVE değerleri ise $24 \mathrm{~g} / \mathrm{cm}^{2}$ ile $74 \mathrm{~g} / \mathrm{cm}^{2}$ arasında belirlenmiştir. En yüksek GVE değeri $74 \mathrm{~g} / \mathrm{cm}^{2}$ ile 7'li gövde grubunda belirlenirken, bunu $66 \mathrm{~g} / \mathrm{cm}^{2}$ ile 10 gövdeli, $63 \mathrm{~g} / \mathrm{cm}^{2}$ ile 8 gövdeli ve $61 \mathrm{~g} / \mathrm{cm}^{2}$ ile 14 gövdeli ocaklar izlemiștir. En düşük GVE değerleri 5 ve 6 gövdeli ocaklarda kaydedilmiștir (Çizelge 7). Gövde verim etkinliğini Şen (2018) farklı güneşlenme koşullarına sahip fındık bahçelerinde konvansiyonel olarak yetiştirilen Palaz çeşidinde 5-7 $\mathrm{g} / \mathrm{cm}^{2}$, İslam ve Çalış (2018) Perşembe (Ordu) yöresinde konvansiyonel olarak yetiştirilen Tombul çeşidinde 12-21 g/cm², Balık ve ark. (2014), konvansiyonel olarak yetiştirilen Tombul çeşidi klonlarında 11-40 g/ $\mathrm{cm}^{2}$ ve Bilgen ve ark. (2017) Ordu'da konvansiyonel olarak yetiştirilen Çakıldak klonlarında $11-54 \mathrm{~g} / \mathrm{cm}^{2}$ arasında bildirmiştir. Verim etkinliği bakımından araştırma bulguları arasında farklılıklar bulunmaktadır. Bu durumun, konvansiyonel üretimde farklı ekoloji, çeşit, teknik ve kültürel uygulama, beslenme koşullarından kaynaklı olabileceği düşünülmektedir.

Çizelge 8'de görüldüğü gibi, çalışmada $5,6,7,8,10$, 12 ve 14 gövdeli ocakların geliştikleri taç iz düşüm alanları sırasıyla $20.4 \mathrm{~m}^{2}, 22 \mathrm{~m}^{2}, 28.3 \mathrm{~m}^{2}, 36.3 \mathrm{~m}^{2}$, $37.4 \mathrm{~m}^{2}, 38.5 \mathrm{~m}^{2}$ ve $40.7 \mathrm{~m}^{2}$ olarak ölçülmüştür. 5, 6, $7,8,10,12$ ve 14 gövdeli yetiștiricilikte; dekara düşen ocak sayıları sırasıyla 49, 45.4, 35.3, 27.5, 26.7,
25.9 ve 24.5; dekara düşen gövde (bitki) sayısı sirasiyla 245, 272.7, 247.4, 220.4, 267.4, 311.6 ve 343.9 ; dekara verim ise sirasiyla $59.9 \mathrm{~kg}, 69.2 \mathrm{~kg}$, $121.8 \mathrm{~kg}, 131.2 \mathrm{~kg}, 140.9 \mathrm{~kg}, 147.2 \mathrm{~kg}$ ve $179.1 \mathrm{~kg}$ olarak hesap edilmiştir. Ocak iz düşüm alan değerleri, ocaktaki gövde sayısı artışına paralel olarak, ocakların bahçede daha geniş alanda geliștiklerini göstermiştir. Buna göre, 14 gövdeli ocaklar bahçelerde 5, 6 ve 7 gövdeli ocaklardan \%144-200 daha fazla alan kaplayıp, daha geniş bir yetișme alanında gelișmișlerdir. Ayrıca, gövde sayısı fazla olan ocaklarda gövdelerin ocak içerisinde düzenli dağıtıldığı ve bahçelerde teknik ve kültürel uygulamaların özenle yapıldığı gözlemlenmiştir. Bütün bunlar, bu araştırmada gövde sayısının artışına paralel olarak ocak verimdeki yükselmenin kanımızca başlıca nedenlerini oluşturmuştur.

Fındık yetiştiriciliği ülkemizde yaygın olarak ocak sistemiyle yapılmaktadır (Beyhan, 2007). Bu sistemde ocaktaki gövde sayısının 6 ile 12 arasında olması yetiştiricilikte kabul görmektedir (Bostan, 2005). Bak (2010) Ordu'da konvansiyonel olarak 4, $5,6,7,8,9$ ve 10 gövdeli yetiștirilen Palaz ocaklarında bırakılabilecek gövde sayısının 8'i geçmemesi gerektiğini bildirmiştir. Palaz findık çeşidinin diğer Türk findık çeşitlerine göre daha zayıf bir gövde ve taç gelişimi sergilediğini belirten Beyhan (2007), bu fındık çeşidinde çit dikim sistemiyle dekara 200, 300, 400, 500 ve 600 bitki düşecek şekilde bitki yoğunluğunu araştırmış, en yüksek ürün miktarına dekara 600 bitki sıklığı ile ulaşıldığını bildirmiştir. 
Çizelge 8. Organik olarak yetiştirilen Palaz findık çeşidinde ocaktaki gövde sayısına bağlı olarak hesap edilen dekara ocak ve gövde sayıları ile verim $(\mathrm{kg})$ değerleri.

\begin{tabular}{ccccc}
\hline $\begin{array}{c}\text { Gövde } \\
\text { Sayısı/ } \\
\text { Ocak }\end{array}$ & $\begin{array}{c}\text { Ocak iz } \\
\text { düşüm } \\
\text { alanı }\left(\mathrm{m}^{2}\right)\end{array}$ & $\begin{array}{c}\text { Dekara } \\
\text { düșen } \\
\text { ocak }\end{array}$ & $\begin{array}{c}\text { Dekara } \\
\text { düșen } \\
\text { gövde }\end{array}$ & $\begin{array}{c}\text { Verim } \\
\text { (kg/dekar) }\end{array}$ \\
\hline 5 & 20.4 & 49.0 & 245.0 & 59.9 \\
6 & 22.0 & 45.4 & 272.7 & 69.2 \\
7 & 28.3 & 35.3 & 247.4 & 121.8 \\
8 & 36.3 & 27.5 & 220.4 & 131.2 \\
10 & 37.4 & 26.7 & 267.4 & 140.9 \\
12 & 38.5 & 25.9 & 311.6 & 147.2 \\
14 & 40.7 & 24.5 & 343.9 & 179.1 \\
\hline
\end{tabular}

Bilindiği gibi, ülkemizde dekara fındık verimi düşüktür. Nitekim, 2017 yılı verilerine göre Türkiye'de dekara findık verim $64.2 \mathrm{~kg}$ civarındadır (Anonim, 2017b). Bu miktarın sahaya yansıyan araştırmalarla yükseltilmesi gerekmektedir. Bu araştırmanın bulguları, ocak sistemiyle organik olarak yetiştirilen Palaz fındık çeşidinde gövde başına 595 g, ocak başına 7.3 kg ve dekara $179.1 \mathrm{~kg}$ ürün elde edildiğini göstermiștir.

\section{Sonuç ve Öneriler}

$\mathrm{Bu}$ araştırma sonucunda, organik olarak yetiştirilen Palaz findık çeşidinde ocakta bırakılan gövde sayısına bağlı olarak meyve özelliklerinde çok dikkat çekici değişiklikler belirlenmezken, ocak başına verimde ve dekara verimde gövde sayısındaki artışa paralel olarak artışlar kaydedilmiştir. Ocak başına ve dekara hesaplanan en düşük verim değerleri 5-6 gövdeli ocaklardan, en yüksek verim değerleri ise daha geniş dikim mesafesi olan 10-12-14'lü ocaklardan elde edilmiştir. Bunun yanında, en yüksek gövde (bitki) başına verim ise 8 gövdeli ocaklardan alınmıştır. Fındıkta verim ve kalite değerlerindeki değişimin ocaktaki bitki sayısı yanında birim alana dikilen ocak sayısı ile de ilgili olduğu ortaya çıkmıştır. Ülkemiz organik fındık yetiştiriciliğinde farklı dikim sistemlerinde çeşitlerin verim ve meyve kalite özelliklerini ortaya koyan geniş çaplı detaylı araştırmalara ihtiyaç bulunmaktadır.

\section{Teşekkür}

$\mathrm{Bu}$ araştırma, Ordu Üniversitesi Bilimsel Araștırma Projeleri Birimince (BAP) desteklenen TF-1639 nolu projenin bir bölümünden üretilmiş olup, projeye maddi desteğinden dolayı Ordu Üniversitesi Bilimsel Araştırma Projeleri Birimine (BAP) teşekkür ederiz.

\section{Kaynaklar}

Akçin, Y., 2010. Findıkta verim ve verime etki eden bazı özellikler arasındaki ilişkiler. Ordu Üniversitesi, Fen Bilimleri Enstitüsü, Yüksek Lisans Tezi. 68 s, Ordu.

Altındişli, A. ve İlter, E., 2002. Ekolojik tarımda ilke ve kavramlar. Emre Basımevi, İzmir.

Anonim, 2017a. Gıda, Tarım ve Hayvancılık Bakanlığı Verileri. https://www.tarim.gov.tr.

Anonim, 2017b. Food and Agriculture Organization of the United State. http://www.fao.org.

Anonim, 2019a. Food and Agriculture Organization of the United State. http://www.fao.org.

Anonim, 2019b. Tarım ve Orman Bakanlığı verileri. https://www.tarimorman.gov.tr

AOAC, 1990. Official methods of analysis (17th ed.). Washington, DC: Association of Official Analytical Chemists.

Aydoğan, M., 2012. Samsun ilinde konvansiyonel ve organik fındık yetiştiricilerinin gübre kullanımı konusundaki iletişim kaynaklarının sosyal ağ analizi ile karşılaştırılması. OMÜ Fen Bilimleri Enstitüsü Tarım Ekonomisi, Yüksek Lisans Tezi. Samsun, $197 \mathrm{~s}$.

Ayfer, M., Uzun, A., Baş, F., 1986. Türk fındık çeşitleri. Karadeniz Bölgesi Fındık ve Mamülleri İhracatçıları Birliği Yayınları, Ankara s.95.

Bak, T., 2010. Findıkta (Corylus avellana L.) farklı dal sayılarının kalite faktörleri üzerine etkileri. Ordu Üniversitesi, Fen Bilimleri Enstitüsü, Bahçe Bitkileri Anabilim Dalı, Yüksek Lisans Tezi. Ordu, $110 \mathrm{~s}$.

Bak, T. Karadeniz, T., Şenyurt, M., Kırca, B., Kırca, S., 2014. Formation of çotanak groups according to direction of branches in the ocaks Tombul and Palaz in hazelnut varieties. Turkish Journal of Agricultural and Natural Sciences. Special Issue: 1: 831-834.

Balık, H. İ, Beyhan, N., 2014. Ordu'nun Ünye ilçesinde palaz fındık çeşidinin klon seleksiyonu. Anadolu Tarım Bilimleri Dergisi, 29(3): 179-185.

Balık, H. İ., Balık, S. K., Köse, Ç. B., Duyar, Ö., Sıray, E., Sezer, A., Turan A., Beyhan, N., Erdoğan, V., İslam, A., Kurt, H., Ak, K., Kalkışım, Ö., 2014. Development of the New Cultivars of Hazelnut by Selection from Tombul Hazelnut Populations in Giresun and Trabzon Provinces. International Mesopotamia Agriculture Congress (22-25 September 2014, Diyarbakır), 172-179.

Balta, F., Balta, M. F., Karadeniz, T., 1997. The Evaluations on preselection of the hazelnut Tombul and Palaz cultivars grown in Çarşamba and Terme (Samsun) districts. Acta Horticulturae, 445: 109-118. 
Balta, M. F., Balta, F., Yarılgaç, T., Karakaya, O., Uzun, S., Kırkaya, H., 2018a. Nut characteristics of 'Fosa' and 'Kargalak' hazelnuts related to number of nuts per cluster. Acta Horticulturae, 1226: 167-170.

Balta, M. F., Yarılgaç, T., Balta, F., Kul, E., Karakaya, 0. 2018b. Effect of elevation and number of nuts per cluster on nut traits in 'Cakıldak' hazelnut. Acta Horticulturae, 1226: 161-166.

Baş, F., Ömeroğlu, S., Türdü, S., Aktaş, S., 1986. Önemli Türk fındık çeşitlerinin bileşim özelliklerinin saptanması. Gıda Mühendisliği Dergisi, 11(4): 1995-203.

Beyhan, N., 2007. Effects of planting density on yield and quality characteristics of hazelnut (cv. Palaz) in a hedgerow training system. Canadian Journal Plant Science, 87: 595-597.

Beyhan, N., Demir, T., Turan, A., 2007. İlkbahar dönemi iklim koşullarının fındığın verim ve gelişmesi üzerine etkileri. Türkiye V. Ulusal Bahçe Bitkileri Kongresi (4-7 Eylül, Erzurum) Bildirileri, 459-463.

Bilgen, Y., Duyar, Ö., Balık, H. İ., Kayalak, B. S., Bostan, S. Z., Koç, G.S., 2017. Clonal selection of 'Çakıldak' hazelnut cultivar in Ordu province of Turkey. International Agriculture Science Congress, 15-19 August 2017, Atakum, Samsun.

Bostan, S. Z. 1997. Tombul, Palaz ve Sivri çeşitlerinde çotanaktaki meyve sayısı ile diğer bazı özellikler arasındaki ilişkilerin belirlenmesi. YYÜ Ziraat Fakültesi, Tarım Bilimleri Dergisi, 7: 23-27.

Bostan, S. Z., 2005. Findıkta pomolojik ve teknolojik özellikler üzerine ocaktaki dal sayısının etkisi. Ziraat Mühendisliği, 344: 4-7.

Bostan, S. Z., Karadeniz, T., 2004. Tombul Fındık çeşidinde meyve ve toprak özelliklerinin rakıma göre değişimi ve bunlar arasındaki ilişkilerin belirlenmesi. 3. Milli Fındık Şurası, s10-14, 10-14 Ekim 2014, Giresun.

Bostan, S. Z., İslam, A., 1999. Ordu'da yetiştirilen Tombul ve Palaz fındık çeşitlerinde beyazlama oranı üzerine farklı sıcaklık ve sürelerin etkileri. Karadeniz Bölgesi Tarım Sempozyumu Bildirileri, 537-546.

Bostan, S. Z., 1997. Tombul, Palaz ve Sivri çeşitlerinde çotanaktaki meyve sayısı ile diğer bazı özellikler arasındaki ilişkilerin belirlenmesi. Yüzüncü Yıl Üniversitesi Ziraat Fakültesi Tarım Bilimleri Dergisi, 7: 23-27.

Bostan, S. Z., Karadeniz, T., Yarılgaç, T., İslam, A., 2008. Modern fındık tekniklerinin uygulanmasına yönelik eğitim projesi ders notları. (Editörler: Levent Kırca, Tuba Bak).

Eryılmaz, G. A., Kılıç, O., 2019. Türkiye'nin Organik Fındık Üretimi ve İhracatındaki Gelişmeler. Firat
Üniversitesi, İIBF Uluslararası İktisadi ve İdari Bilimler Dergisi, 3(1): 41-54.

Güler, E., 2017. Taşkesti (Mudurnu-Bolu) beldesi fındık populasyonunun verim ve kalite özelliklerinin belirlenmesi. Ordu Üniversitesi, Fen Bilimleri Enstitüsü, Yüksek Lisans Tezi. Ordu, 63 s.

İslam, A., 2003. Clonal selection in 'Uzunmusa' hazelnut. Plant Breeding, 122(4): 368-371.

İslam, A., 2018. Hazelnut culture in Turkey. Akademik Ziraat Dergisi, 7 (2): 259-266.

İslam, A., Özgüven, A.I., 1997. Türkiye'de fındık yetiştiriciliği. Çukurova Üniversitesi Ziraat Fakültesi Dergisi, 12(4):165-174.

İslam, A., Ozgüven, A.I., 2001. Clonal selection in the Turkish hazelnut cultivars grown in Ordu province. Acta Horticulture, 556: 203-208.

İslam, A., Çalış, L. 2018. Yield and nut characteristics of 'Tombul'hazelnut growing at different elevations and in different orientations. Acta Hortic. 1226: 153-156.

Karadeniz, T., Bostan, S. Z., Tuncer, C., Tarakçıŏlu, C., 2009. Fındık Yetiştiriciliği. Ziraat Odası Başkanlığ Bilimsel Yayınlar Serisi, 154 s. Ordu

Karaosmanoğlu, H., 2018. Organik Fındığın Besinsel Karakterizasyonu. Ondokuz Mayıs Üniversitesi, Fen Bilimleri Enstitüsü, Gıda Mühendisliği Anabilim Dalı, Doktora Tezi. Ordu, 213s.

Kırca, L., 2010. Findıkta (Corylus avellana L.) ocak dikim yașı ile verim ve kalite arasındaki ilișkiler. Ordu Üniversitesi, Fen Bilimleri Enstitüsü, Yüksek Lisans Tezi. 53 s, Ordu.

Külahçılar, A., Tonkaz, T., Bostan, S. Z., 2018. Effect of irrigation regimes by mini sprinkler on yield and pomological traits in 'Tombul' hazelnut. Acta Horticulturae, 1226: 301-308.

Özenç, N., 2004. Findık zurufu ve diğer organik materyallerin findık tarımı yapılan toprakların özellikleri ve ürün kalitesi üzerine etkileri. Ankara Üniversitesi, Fen Bilimleri Enstitüsü. Doktora Tezi 399s, Ankara.

Özkutlu, F., Korkmaz, K., Özenç, N., Aygün, A., Şahin, Ö., Kahraman, M., Ete, Ö., Akgün, M., Taşkin, B. 2016. Determination of Mineral Nutrition Status of Some Hazelnut Gardens in Ordu. Akademik Ziraat Dergisi. 5(2):77-86.

Özyazıcı, G., Özdemir, O., Özyazıcı, M.A., Üstün, G.Y., Turan, A., 2010. Bazı organik materyallerin ve toprak düzenleyicilerin organik fındık yetiștiriciliğinde verim ve toprak özellikleri üzerine etkileri. Türkiye 4. Organik Tarım Sempozyumu, 28 Haziran-1 Temmuz, Bildiriler Kitabı, 368-372s. Erzurum.

Şen, Y., 2018. Farklı Güneşlenme Şartlarının Tombul ve Palaz Fındık Çeşitlerinde Verim ve Kalite 
Özelliklerine Etkisi. Ordu Üniversitesi, Fen Bilimleri Enstitüsü, Yüksek Lisans Tezi. 48 s. Ordu

Turan, A, Sezer, A. ve Ak, K., 2007. Bazl organik materyallerin findıkta verim ve kalite üzerine etkisi. Türkiye 5. Ulusal Bahçe Bitkileri Kongresi, 04-07 Eylül, Bildiri Kitabı, 1. Cilt (Meyvecilik), 607610s, Erzurum.
Venkatachalam, M., Sathe, S.K., 2006. Chemical composition of selected edible nut seeds. Journal of Agricultural and Food Chemistry, 54(13): 47054714.

Yaman, İ., 2019. Çarșamba (Samsun) İlçesinde Bakımlı ve Bakımsız Fındık Bahçelerinde Yetiştirilen Çakıldak Çeşidinin Verim ve Meyve Özeliklerinin Belirlenmesi. Ordu Üniversitesi, Fen Bilimleri Enstitüsü, Yüksek Lisans Tezi. Ordu, 61 s. 